\title{
THE NATURE OF SELF-EMPLOYMENT IN URBAN ETHIOPIA ${ }^{1}$
}

\author{
Getinet Astatike Haile ${ }^{2}$
}

\begin{abstract}
Various studies on the Ethiopian economy in general and the urban sector in particular have stated about the staggering level of unemployment in the country. Rapidly growing population and a less than satisfactory performance in economic growth over the years, among others, are to blame for this situation. That the unemployment situation is particularly rampant among the youth which constitutes over a third of the population calls for an urgent intervention aimed at improving the fate of the unemployed. Promoting self-employment forms an integral part of any intervention aimed at reducing unemployment. Given this, studying the determinants of self-employment is essential by way of informing concerned parties as to factors important in encouraging self-employment. As well as surveying the relevant literature, the study undertakes an empirical investigation into the nature of selfemployment using data from a unique panel data set, the Ethiopian Urban SocioEconomic Survey. Findings of the study give some evidence that self-employment is largely a route out of unemployment rather than being something driven by entrepreneurship. It also finds a declining trend in the patterns of self-employment over the study period. Very few studies have looked into issues relating to selfemployment in the context of developing countries in general, and none in the case of Ethiopia. As such, this study serves an important role shedding some light on issues pertaining to self-employment.
\end{abstract}

Key words: Self-employment; urban Ethiopia

JEL classification: J23; J33; R23

\footnotetext{
${ }^{1}$ The final version of this article was submitted in February 2009.

${ }^{2}$ Correspondence address: Policy Studies Institute, 50 Hanson Street, London, W1W 6UP, email: g.haile@psi.org.uk
} 


\section{Introduction}

Various recent studies ${ }^{3}$ have stated about the unprecedented level of unemployment that characterises urban Ethiopia. ${ }^{4}$ The problem is rampant especially among the youth which constitutes over a third of the urban population. That the youth, which is the future of the country, is found in such a state is unfortunate and rather disquieting. One way of tackling this problem of unemployment is through the promotion of selfemployment. That the State in countries such as Ethiopia is poor means that the promotion of self-employment is all the more essential in easing the high level of unemployment. Sustained growth performance accompanied by rapid employment creation is ultimately to decide the fate of the unemployed. Nevertheless, the promotion of self-employment can play a crucial role in this process. On a more optimistic note, the promotion of self-employment may even have a far reaching positive outcome. The accepted wisdom is that the development of new firms almost always starts with self-employment, and this may turn out to be particularly essential to capital-constrained developing economies such as Ethiopia. Given these, understanding the nature of self-employment is important for it makes possible an informed intervention. This paper investigates issues surrounding self-employment in the context of urban Ethiopia. In particular, the study focuses on factors that influence the decision to be self-employed.

This study is unique on at least three important grounds. First, there are very few previous studies investigating issues of self-employment in the context of a developing country, and none in the case of Ethiopia. Second, this study uses a unique panel data, the Ethiopian Urban Socio-Economic Survey (EUSES), which has rarely been used previously. Third, the study employs an empirical methodology that accounts for unobserved heterogeneity. Although most researchers agree on the importance of unobserved factors (for example, unobserved entrepreneurial ability) in determining the decision to be self-employed, no previous study models unobserved heterogeneity exclusively. As such, this study also adds a new dimension to the selfemployment literature.

The study has the following sections. Section 2 is devoted to some background discussion with focus on the urban labour market and the unemployment situation in urban Ethiopia, particularly among the urban youth. Section 3 is devoted to some

\footnotetext{
${ }^{3}$ Bizuneh et al. (2001), Getinet (2003), Serneels (2001) and Krishnan et al. (1998) are some of the studies dwelling on the labour market situation of the youth/'young' in Ethiopia. Findings reported in various publications of the UN give a similar account of the unemployment situation in Ethiopia.

${ }^{4}$ Unemployment rate related discussion in the developing world is largely an urban phenomenon for in the rural areas, where the bulk of the population resides; the unemployment rate may not be as reliable given the seasonality in labour market slack in these areas.
} 
discussion on the underlying theoretical framework and review of the literature on self-employment. Section 4 discusses the data and the empirical methodology employed. Section 5 discusses the empirical findings and the final section concludes the paper.

\section{Background}

The Ethiopian economy is essentially a subsistence-agriculture economy. Some 80 per cent of the population ${ }^{5}$ resides in rural areas driving its livelihood directly from agriculture and animal husbandry, and contributing 52 per cent of the country's GDP. The urban centre is home to about 20 per cent of the population with some 12 per cent of this driving its livelihood from government and services while the remaining 8 per cent relying on industry and construction. A number of recent studies that have focused on different aspects of the urban labour market in Ethiopia (Bizuneh et al., 2001; Getinet, 2003; Krishnan, 1996, 2001; Krishnan et al., 1998; Serneels, 2001) have emphasised the unprecedented level of unemployment in the urban centres of the country, particularly among the youth/young.

Several factors are to blame for this sad state of affair. To start with, there is the unprecedented rate of growth of the (urban) population. The larger the size of the youth cohort, the more daunting the provision/generation of accommodating employment will generally be. That the growth and job creation performance of the economy has been disappointing for the most part is another important reason explaining the high level of unemployment. Poor growth performance and weak aggregate demand is a recipe for disaster when combined with growing youth/adult labour force in need of employment. The mismatch between the skill requirements of the labour market on the one hand and the education/training skills of the youth/young on the other is also another factor held responsible for the high and persistent levels of unemployment in the urban centres. That private sector development had been openly stifled in the pre-1991 period and has been given minimal support since then is yet another reason contributing to the current high level of unemployment in Ethiopia. The move to a market led system in the post-1991 period, which commenced with the adoption of the WB/IMF sponsored structural adjustment program, marked a major departure from the previous policy regime. Nonetheless, performance in employment creation has particularly been poor despite some improvement in growth performance. Krishnan (2001) attributes this to the fact that the private sector and self-employment has not yet overcome the effect of the repression it had experienced in the pre-1991 period. Alemayehu and Befekadu

\footnotetext{
${ }^{5}$ Recent UN sources/estimates put the population of Ethiopia to be in excess of 74 million.
} 
(2002), on the other hand, state that the recent improved growth performance came largely from the rural sector which is weakly linked to the urban sector. ${ }^{6}$

\section{Self-employment: theoretical background and some stylized facts/evidence}

The issue of self-employment has gained more ground in the economics literature relatively recently. Moreover, the existing literature dwells largely on developed economies, with very little to offer to the labour market situation of a developing country such as Ethiopia. The theoretical argument behind the self-employment decision is one that is based on labour market states as choice variables determined by expected utility from each labour market state. Following Evans and Jovanovic (1989), Evans and Leighton (1989) and Taylor (1996; 1999), suppose that the expected utility from self-employment, $E\left(U_{\mathrm{se}}\right)$, and employment, $E\left(U_{\mathrm{e}}\right)$ are given as follows

$$
\begin{aligned}
& E\left(U_{s e}\right)=f(\theta, k, r, D, \mathbf{X}) \\
& E\left(U_{e}\right)=f(w, \mathbf{X})
\end{aligned}
$$

where $\theta$ represents entrepreneurial ability, $k$ represents available capital, $r$ is the rate of interest, $D$ stands for the level of demand in the economy, $w$ stands for the wage rate and/or wage offer, and $\mathbf{X}$ represents individual tastes and preferences. Suppose also that individuals receive no utility from being unemployed and/or being out of the labour force (OLF), i.e. $E\left(U_{u}\right)=E\left(U_{\text {olf }}\right)=0$. Given this framework and assuming that $E\left(U_{u}\right)=E\left(U_{\text {olf }}\right)=0$, the self-employment decision lies in comparing $E\left(U_{\text {se }}\right)$ and $E\left(U_{\mathrm{e}}\right)$. Thus, an individual will prefer self-employment over wage employment (or wage offer) if: $E\left(U_{s e}\right)>E\left(U_{e}\right)$.

This framework has some important implications. For example, individuals would voluntarily cease to be in self-employment if a wage offer, $w$, warranties that $E\left(U_{e}\right)>E\left(U_{s e}\right)$. Likewise, individuals who perceive to have high entrepreneurial ability, who have access to capital and/or favourable rate of interest, among others, may prefer to be/stay in self-employment. As stated in section 2 above, in the context of the urban centre of developing countries in general and Ethiopia in particular there

\footnotetext{
${ }^{6}$ It is noteworthy the anecdotal evidence relating to the expansion of party-affiliated businesses (parastatals) in post-1991 Ethiopia. To the extent that this is the case, small businesses and the private sector are likely to be crowd out.
} 
is very high and persistent unemployment. The implication of this is that expected earnings from self-employment are likely to be lower relative to expected employment earnings. Given the assumption $E\left(U_{u}\right)=E\left(U_{\text {olf }}\right)=0$, the pattern of preference/choice among alternative labour market states identified is to be $E\left(U_{e}\right)>E\left(U_{s e}\right)>E\left(U_{u}\right)=E\left(U_{\text {olf }}\right)$. In other words, in an environment where jobs /wage offers/ are hard to come by for the large army of the unemployed, selfemployment is almost certainly a preferred labour market state to being in unemployment and/or inactivity.

The existing literature on self-employment raises various issues of importance worth noting here. First, there is the conceptual and measurement issue that deserves particular attention. As Earle and Sakova (2000) state, a self-employed worker may represent a 'true' entrepreneur running successful business, exploiting new opportunities and inventing new products, processes and distribution methods. At the other extreme, we may have a self-employed worker who chose to be self-employed due only to lack of opportunities elsewhere. Similarly, "a high rate of self-employment may reflect an environment encouraging risk-taking, job creation, and market development, or it may indicate a lack of jobs in a primary sector in which wages are set above the market-clearing level. An increase in the self-employment rate may represent entrepreneurship derived from economic liberalization and tax reduction, or it may be a consequence of imperfect adjustment to contractions or structural shocks" (Earle \& Sakova, 2000, p. 576).

The self-employment literature also makes some claims that have not yet been proved conclusively for the most part. One such claim is that self-employment helps promote invention, innovation and the creation of new jobs. ${ }^{7}$ The promotion of selfemployment/small business is also claimed to lead to a higher degree of competition in the product market, bringing gains to consumers. Greater levels of selfemployment are also linked to increased self-reliance and well-being. Despite lack of conclusive evidence on these claims and the advantages of promoting selfemployment, some governments, particularly those in developed market economies, provide various types of support to encourage the unemployed to start own business. The types of support these governments provide include loans to small businesses, exemption of small businesses from certain regulations, exemption of small business from some taxes and an advisory service to beginner small businesses (Blanchflower, 2000; 1999)

\footnotetext{
7 These claims/arguments are in line with the benefits of entrepreneurship that Schumpeter (1942) identifies, and can be justified if one assumes that self-employment represents the simplest kind of entrepreneurship
} 
With regards to characteristics that best describe the self-employed, the existing literature identifies some important factors that include access to capital and liquidity constraint, certain demographic and human capital characteristics, family background related factors, local/regional labour market conditions, and policy/institution related factors, among others. In terms of access to capital, the literature states that lack of capital and liquidity constraint affect the propensity to be self-employed adversely (Blanchflower, 1999, 2000; Blanchflower and Oswald, 1998). These studies also find that the propensity to be self-employed depends positively on whether the individual in question ever received an inheritance or gift. Regarding the role of institutions and/or policy, there is some evidence in the literature that attests to the positive effect of increases in income tax on self-employment. The existing evidence also points to the strong negative relationship between unemployment and self-employment. In terms of demographic characteristics, the evidence suggests that the probability of being self-employed is generally higher among men than women, and it is also found to increase with age. With regards to the educational profile of the self-employed, they are more likely to come from the least educated. There exists some evidence, however, that the most educated too have a higher probability of being self-employed (Blanchflower and Oswald, 1990; Blanchflower, 1999; 2000; Earle and Sakova, 2000; Taylor, 1996).

\section{Data and empirical methodology}

The data employed in this study comes from a unique panel data set collected by the Ethiopian Urban Socio-Economic Survey (EUSES) over the period $1994-2000$. The EUSES is a national survey of urban households that has been undertaken by the Department of Economics, Addis Ababa University, in collaboration with the Department of Economics, Goteborg University. The first wave of the EUSES was conducted in 1994 covering seven major urban centres of the country, including the capital city, each with a population in excess of 100,000 and believed to represent the major socio-economic characteristics of urban Ethiopia. The original EUSES sample households had been selected by allocating a total sample size of 1500 households to the seven urban centres based on stratified random sampling technique. The first survey that was conducted in 1994 therefore covered these 1500 households. The second and third waves of the EUSES were conducted in 1995 and 1997 covering the original households ${ }^{8}$, but capturing only changes on socio-economic conditions since the first/previous wave. The most recent wave available is the fourth wave that

\footnotetext{
${ }^{8}$ Subsequent waves covered the original households. Households that dropped out in subsequent waves were replaced by other/new households that are believed to be more or less similar to the original households, in terms of socio-economic characteristics.
} 
was conducted in 2000. Unlike the preceding two waves where only changes from the previous wave were monitored, the 2000 wave enlists each and every member in the households (Bigesten et al, 2004). In this study, use is made of all four sweeps of the EUSES for the purpose of studying the nature of self-employment in urban Ethiopia.

In terms of the empirical methodology employed to study the nature of selfemployment, a panel data binary choice model that accounts for unobserved individual heterogeneity has been used. That we have, for each individual included in the sample, a binary outcome variable of self-employment, $y_{i t}$, for each of $T=4$ time periods justifies the use of panel data binary choice model.

Suppose that $\left\{\left(\mathbf{y}_{i t}, \mathbf{x}_{i t}\right): t=1, \ldots, T=4\right\}$ represent a random draw from the cross section for each individual, $i$, where $\boldsymbol{y}_{i t}$ and $\mathbf{x}_{i t}$ can both be vectors; we then assume and model that there is an unobserved heterogeneity, $\boldsymbol{v}_{i}$, associated with each cross section unit $i$. Using unobserved effects probit model, the propensity to be selfemployed can be assumed to take the form

$$
P\left(y_{i t}=1 \mid \mathbf{x}_{i t}, \theta_{i}\right)=\boldsymbol{\Phi}\left(\mathbf{x}_{i t} \boldsymbol{\beta}+v_{i}\right), \quad t=1, \ldots, 4
$$

with $v_{i}$, appearing additively in the index function and $\mathbf{x}_{i t}$ containing a full set of time dummies. Because we specifically account for unobserved heterogeneity, it is safe to assume that $y_{i t}$ are dependent across $t$ conditionally only on the observables, $\mathbf{x}_{i}$. The density of $\left(y_{i 1}, \ldots . y_{i T}\right)$ conditional on $\left(\mathbf{x}_{i}, v_{i}\right)$ can be given as

$$
f\left(y_{1}, \ldots, y_{T} \mid \mathbf{x}_{i}, v_{i} ; \boldsymbol{\beta}\right)=\prod_{t=1}^{T} f\left(y_{t} \mid \mathbf{x}_{i t}, v_{i} ; \boldsymbol{\beta}\right)
$$

where $f\left(y_{t} \mid \mathbf{x}_{t}, v ; \boldsymbol{\beta}\right)=\boldsymbol{\Phi}\left(\mathbf{x}_{t} \boldsymbol{\beta}+v\right)^{y_{t}}\left[1-\boldsymbol{\Phi}\left(\mathbf{x}_{t} \boldsymbol{\beta}+v\right)\right]^{1-y_{t}}$ (Wooldridge, 2002). The relevant log-likelihood function of interest is then given by

$$
L(\boldsymbol{\beta}, v)=\sum_{i=1}^{N} \sum_{t=1}^{T}\left\{y_{i t} \log \left[\boldsymbol{\Phi}\left(\mathbf{x}_{i t} \boldsymbol{\beta}+v_{i}\right)\right]+\left(1-y_{i t}\right) \log \left[1-\boldsymbol{\Phi}\left(\mathbf{x}_{i t} \boldsymbol{\beta}+v_{i}\right)\right]\right\}
$$

An empirical issue of importance at this stage has to do with the nature/distribution of the unobserved heterogeneity term, $v_{i}$. The traditional random effects probit model 
makes the rather strong assumption that $v_{i} \mid x_{i} \sim \operatorname{Normal}\left(0, \sigma_{v}^{2}\right)$. That this assumption implies that $v_{i}$ and $\mathbf{x}_{i}$ are independent and that $v_{i}$ has a Gaussian distribution may prove to be implausible, for $v_{i}$, by definition, has an unknown distribution. The omitted variable that $v_{i}$ stands for might, for example, be represented by a categorical variable, making the normality assumption inappropriate. In the face of such possible drawback, the best alternative is to model the unobserved heterogeneity term non-parametrically. In this study, unobserved heterogeneity is modelled non-parametrically by using a discrete mass point distribution for the heterogeneity term $v$ and its density function $g_{v}(v)$. Representing the distribution of mass points by a number of finite locations $\theta_{1}, \ldots, \theta_{m}$ and associated probabilities for each mass point $\pi_{1}, \ldots, \pi_{m}$, the number and location of the mass points and associated probabilities has been estimated together with other parameters of interest. ${ }^{9}$ The additional parameters characterising the unobserved heterogeneity term should satisfy the condition that $\sum_{m=1}^{M} \pi_{m}=1, \pi_{m} \geq 0$ and $\sum_{m=1}^{M} \pi_{m} \theta_{m}=0$, however.

To account for the conceptual and measurement issues raised in section 3 of this study, alternative definitions of self-employment have been used. First, we make use of a narrow and a broader definition of self-employment. The narrow definition regards the self-employed as only those that are employers. The broader definition of self-employment, on the other hand, includes those that are own account workers and those involved in household female business activity. Secondly, the comparison group for the self-employed has been made to account for the different labour market states possible. Accordingly, the first version of models estimated has a dependent variable that assumes a value of 1 if an individual is self-employed and 0 if an individual is (wage) employee. The second version of models has a dependent variable that assumes a value of 1 if an individual is self-employed and 0 if an individual is (wage) employee or unemployed. The third version has a dependent variable that assumes a value of 1 if an individual is self-employed and 0 if an individual is (wage) employee, unemployed or out of the labour force.

\footnotetext{
${ }^{9}$ The estimation of the discrete random effects probit model is conducted using the GLLAMM software (http://www.gllamm.org)
} 


\section{Discussion of results}

As stated in section 4 above, alternative definitions of self-employment and comparison group have been used in the empirical analysis. Looking at the descriptive statistics given in Table 3 in the appendix reveals that there has been a declining trend in the proportion of the self-employed, defined broadly, over the study period. Accordingly, the self-employed make up 19 per cent of the labour force in 1994 but this percentage has declined consistently reaching 16 percent in 2000 . The narrower definition of self-employment which refers to those that are employers, on the other hand, indicate some variability over the period but accounts for roughly 1 per cent of the urban labour force.

In terms of the characteristics of the self-employed, Table 1 and Table 2 in the appendix indicate that the self-employed are unlikely to come from the young, regardless of the type of definition used. Women are significantly less likely to be employers but are more likely to constitute the broader definition of the self-employed which has to do with the inclusion of household female business activity in the broader definition. Those who migrated to the urban centres over a period of 10 years prior to being surveyed are significantly less likely to make up the self-employed irrespective, again, of the type of definition used. In terms of ethnicity and religious background of respondents, the Guraghes are significantly more likely to make up the self-employed defined narrowly while the other ethnic groups are significantly less likely to make up the self-employed. ${ }^{10}$ Such ethnicity related significance tends to disappear when the reference category is made to account for the unemployed and the inactive, however. With regards to religious characteristics, orthodox Christians are significantly less likely to make up the self-employed, defined narrowly, in general while Muslims are more likely to constitute employers compared with their employee counterparts.

The nature of self-employment in terms of educational background of respondents suggest that the self-employed are generally significantly less likely to come from those that have completed at least secondary level education. On the other hand, those with at most primary level education are significantly more likely to form the self-employed defined broadly. This finding is in line with the evidence that the selfemployment literature attests to. The general consensus is that the self-employed are more likely to come from the least educated segment of the labour force that is unlike to get wage offers that would make employment an option. The wider literature does, however, indicate that some, albeit a smaller proportion, of the highly educated

\footnotetext{
${ }^{10}$ This seems to be in line with the traditionally held view that the Guraghes have the edge, in terms of entrepreneurship, over other ethnic groups.
} 
moving into self-employment. In the sample used in this study, the proportion of those that have a tertiary education (or beyond) is rather small which explains the broad category of 'secondary level or more' used in the empirical exercise undertaken.

A finding that does not conform to what the self-employment and micro-enterprise literature suggests is that associated with 'access to credit'. Access to credit does not have the expected sign and significance in this study. ${ }^{11}$ The wider literature suggests lack of capital and/or access to credit being an important impediment to would-be entrepreneurs from being self-employed or, for that matter, for giving up selfemployment. Household/parental background is found to have a significant positive effect, for the most part, in determining the propensity to be self-employed. In particular, those whose father is/was in self-employment are more likely to pick the art of their father. This is not an unexpected finding given the influence that parental career may have on siblings in general. Not surprisingly, the self-employed are significantly more likely to be heads of the household. What is not in line with expectation is the finding that being in Addis Abeba does not have any positive and significant effect on the probability of being self-employed. One would expect urban based self-employment and/or entrepreneurship, if any, to be noticeable in the capital city of the country.

The declining trend in the number of the self-employed, defined narrowly or otherwise, that we observed in the descriptive statistics given in Table 3 in the appendix is further confirmed by the results from the formal modelling exercise. Broadly speaking, the trend in the patterns of self-employment in urban Ethiopia is one of declining. This is again very much counter-intuitive for an economy that claims to have departed from a command system of economic management over a decade or so ago. One would expect to observe a positive, however small in magnitude, trend in the direction of more entrepreneurship and self-employment. Such expectation is justified, irrespective of the weaknesses of the liberalisation measures undertaken in Ethiopia in the post 1991 period and/or other problems that beset this period/system. ${ }^{12}$ Economies that have made a similar transition seem to have created a favourable condition for the development of self-employment and entrepreneurship. For example, in their recent study into the nature of self-employment in former socialist Eastern European countries, Earle and Sakova (2000) find that the level of

\footnotetext{
${ }^{11}$ This may have to do with the 'crude' proxy used in the estimation. The access to credit variable is generated on the basis of the question that monitors whether or not at least one member of a household has a bank account; whether or not at least one member of a household is member of a credit association, or whether or not at least one member of the household is a member of an 'equib'.

${ }^{12}$ It is not uncommon to hear about the charges that international (financial) institutions and the domestic private sector lay against the current government regarding the half-hearted nature of the liberalisation measures undertaken to date and the increasing role that party affiliated companies have in the conduct of business in Ethiopia in the post 1991 period. Both of these are likely to be detrimental to the development of the private sector and the promotion of self-employment in the country.
} 
self-employment has grown extremely rapidly in the post transition period although it was generally very much negligible at the start of transition in 1989.

With respect to the heterogeneity related parameters, we can view the location of the discrete points estimated (the $\theta^{\prime} s$ ) and their respective masses ( $\left.\pi^{\prime} s\right)$ as representing different, four in our case, latent classes of respondents, each representing different levels/propensity to be self-employed. Thus, if we take the narrow definition of selfemployment with employees as the reference category, we can have four distinct groups with probabilities of 14 per cent, 38 per cent, 30 per cent and 18 per cent. The importance of these parameters is in providing us a way to handle unobserved factors that may determine the propensity to be self-employed.

\section{Summary and conclusion}

This study has attempted to shed some light on the nature of self-employment in urban Ethiopia. To this end, the study reviewed the literature on self-employment focusing on the relevant theoretical background and empirical evidence on the same. Findings from the empirical investigation undertaken give some indication that selfemployment is a route out of unemployment rather than being something of an entrepreneurial venture. In particular, findings of the study indicate that the young, the educated, those that migrated to urban areas recently and those without parents in self-employment are less likely to be found in self-employment. Findings regarding the effect of 'access to credit' on the propensity to be self-employed are counterintuitive. This may have to do with the way 'access to credit' has been measured and calls for a further investigation into the role that access to credit plays in determining self-employment.

The finding that there is a declining trend in self-employment is rather puzzling. One would expect a rising trend in self-employment in an economy that departed from a command system of economic management. That the liberalisation process has not gone far off and that government affiliated companies are having increasing role in the economy may, at least in part, explain this pattern. Small businesses and selfemployment are likely to be crowded out when faced with large companies that seem to enjoy preferential treatment. As stated earlier, two important factors that are likely to impact the level of self-employment most are: 1) the availability of an environment that encourages risk-taking and market development and 2) the lack of employment opportunity in the major employer sector of the economy. That there is lack of employment opportunity in the urban sector in Ethiopian is quite apparent. What is not obvious is as to why self-employment has not picked up in the urban sector substantially. This brings to the fore the issue of whether there has been a conducive 
environment, including credit availability, in the urban sector of the country. This is an important question to ponder about. That the growth of entrepreneurship in general and the private sector in particular is commonly associated with innovation, job creation and rapid economic growth makes this assignment all the more important. 


\section{References}

Alba-Ramirez, A. 1994. Self-employment in the Midst of Unemployment: the Case of Spain and the United States, Applied Economics, 26, 189 - 204.

Alemayehu, G. and D. Befekadu. 2002. Explaining African Growth Performance: The Case of Ethiopia, AERC Growth Research Workshop.

Bigesten, A., B. Kebede, A. Shimeles and M. Taddesse. 2003. Growth and Poverty Reduction in Ethiopia: Evidence from Household Panel Surveys, World Development, Vol. 31, No. 1.

Bizuneh, G., T. Adino, G. Gesano, A. Guarneri and F. Heins. 2001. Work Status and Unemployment in Urban Ethiopia, Mimeo, Central Statistical Authority (Addis Ababa, Ethiopia) and Institute for Population Research - National Research Council (Roma, Italy)

Blanchflower, David G. 1999. What Can be Done to Reduce the High Levels of Youth Joblessness in the World? Mimeo, a report commissioned by the ILO.

Blanchflower, David G. 2000. Self-employment in OECD Countries, Labour Economics, 7, 471 $-505$.

Earle, John S. and Z. Sakova. 2000. Business Start-ups or Disguised Unemployment? Evidence on the Character of Self-employment from Transition Economies, Labour Economics, 7, $575-601$.

ECA. 2002. Youth and Employment in the ECA Region, Paper prepared by the UNECA for the Youth Employment Summit in Alexandria, Egypt, September 2002.

Ethiopia Interim Poverty Reduction Strategy Paper: 2000/01 - 2002/03, November 2000, Addis Ababa, Ethiopia.

Evans, D. and Jovanovic, B. 1989. .An Estimated Model of Entrepreneurial Choice under Liquidity Constraints, Journal of Political Economy, 97 (4), 808-27.

Evans, D. and Leighton, L. 1989. Some Empirical Aspects of Entrepreneurship, American Economic Review, 79(3), 519-35.

Getnet Haile A. 2003. The Incidence of Youth Unemployment in Urban Ethiopia, paper presented at the $2^{\text {nd }}$ EAF Conference, July 2003.

ILO- Employing Youth: Promoting Employment Intensive Growth, Paper for the Symposium on Strategies to Combat Youth Unemployment. (http://www.ilo.org/public/english/employment/skills/youth/sympo/tabcontn.htm)

Krishnan, P. 1996. Family Background, Education and Employment in Urban Ethiopia, Oxford Bulletin of Economics and Statistics, 58,1.

Krishnan, P. 2001. Public Sector Pay and Private Sector Wage Premiums: Testing Alternative Models of Wage Determination, University of Cambridge.

Krishnan, P., T. Gebreselassie and S. Dercon. 1998. The Urban Labour Market during Structural Adjustment: Ethiopia 1990 - 1997, Centre for the Study of African Economics

Le, Ahn T. 1999. Empirical Studies of Self-employment, Journal of Economic Surveys, 13 (4), $381-386$.

Prime Minister Office. 1993. - National Population Policy of Ethiopia, Addis Ababa, Ethiopia, April 1993. 
Rabe-Hesketh, S., A. Skrondal and A. Pickles. 2004. GLLAMM Manual, U.C. Berkeley Division of Biostatistics Working Paper Series, Paper 160.

Serneels, P. 2001. Unemployment Duration in Urban Ethiopia, Centre for the Study of African Economics.

Taylor, M. 1996. Earnings, Independence or Unemployment: Why Become Self-Employed?, Oxford Bulletin of Economics and Statistics, 58(2), 253-66.

Taylor, Mark P. 1999. Survival of the Fittest? An Analysis of Self-employment Duration in Britain, The Economic Journal, 109, C140 - C155.

Todaro, P. M. 1997. Economic Development, $7^{\text {th }}$ edition, Longman.

Wooldridge, J. M. 2002. Econometric Analysis of Cross Section and Panel Data. The MIT Press, Cambridge, Massachusetts. 


\section{Appendix: Tables of results and descriptive statistics}

Table 1: Random effects probit estimates of the determinants of self-employment (employers)

\begin{tabular}{|c|c|c|c|}
\hline & $\operatorname{Exp}(b)$ & $\operatorname{Exp}(b)$ & $\operatorname{Exp}(b)$ \\
\hline & 1 & 2 & 3 \\
\hline \multirow[t]{2}{*}{ Age } & $0.78^{\star \star \star}$ & $0.82^{\star * \star}$ & $0.86^{\star * \star}$ \\
\hline & $(0.04)$ & $(0.02)$ & $(0.02)$ \\
\hline \multirow[t]{2}{*}{ Agesq } & $1.004^{\star \star \star}$ & $1.003^{\star \star \star}$ & $1.002^{\star \star \star}$ \\
\hline & $(0.00)$ & $(0.00)$ & $(0.00)$ \\
\hline \multirow[t]{2}{*}{ Female } & $0.10^{\star \star \star}$ & $0.15^{\star \star \star}$ & $0.10^{\star \star \star}$ \\
\hline & $(0.04)$ & $(0.03)$ & $(0.02)$ \\
\hline \multirow[t]{2}{*}{ Married } & $0.38^{\star \star \star}$ & $2.07^{\star \star \star}$ & $2.57^{\star \star \star}$ \\
\hline & $(0.11)$ & $(0.37)$ & $(0.45)$ \\
\hline \multirow[t]{2}{*}{ Migrant } & $0.18^{\star \star \star}$ & $0.56^{\star \star *}$ & 0.71 \\
\hline & 0.08 & 0.12 & 0.15 \\
\hline \multirow[t]{2}{*}{ No health problem } & 1.12 & 0.97 & 0.85 \\
\hline & $(0.29)$ & $(0.15)$ & $(0.12)$ \\
\hline \multirow[t]{2}{*}{ TV set in the house } & 1.11 & $4.74^{\star \star *}$ & $1.51^{\star * \star}$ \\
\hline & $(0.31)$ & $(1.12)$ & $(0.23)$ \\
\hline \multirow[t]{2}{*}{ Amhara } & $0.25^{\star \star \star}$ & $0.15^{\star \star \star}$ & $0.10^{\star \star \star}$ \\
\hline & $(0.09)$ & $(0.04)$ & $(0.03)$ \\
\hline \multirow[t]{2}{*}{ Oromo } & $0.09^{\star * \star}$ & $0.14^{\star \star \star}$ & $0.08^{\star \star \star}$ \\
\hline & $(0.04)$ & $(0.04)$ & $(0.02)$ \\
\hline \multirow[t]{2}{*}{ Tigrawi } & 0.45 & $0.25^{\star \star \star}$ & $0.10^{\star \star \star}$ \\
\hline & $(0.21)$ & $(0.09)$ & $(0.04)$ \\
\hline \multirow[t]{2}{*}{ Gurage } & $10.60^{\star * \star}$ & 0.31 & 0.75 \\
\hline & $(4.99)$ & (0.09) & $(0.20)$ \\
\hline \multirow[t]{2}{*}{ Orthodox Christian } & $0.18^{\star \star \star}$ & $0.14^{\star \star \star}$ & $0.16^{\star \star \star}$ \\
\hline & $(0.09)$ & $(0.04)$ & $(0.04)$ \\
\hline \multirow[t]{2}{*}{ Muslim } & $24.14^{\star \star \star}$ & $1.13^{\star *}$ & $0.43^{\star \star \star}$ \\
\hline & (16.39) & $(0.35)$ & $(0.11)$ \\
\hline \multirow[t]{2}{*}{ Primary level education } & 1.01 & 0.82 & $1.43^{\star \star}$ \\
\hline & $(0.31)$ & $(0.16)$ & $(0.22)$ \\
\hline \multirow[t]{2}{*}{ Secondary or more } & $0.07^{\star \star \star}$ & $0.27^{\star \star \star}$ & 0.99 \\
\hline & $(0.03)$ & $(0.06)$ & $(0.17)$ \\
\hline \multirow{2}{*}{ Access to credit } & $0.28^{\star \star \star}$ & 0.85 & 0.86 \\
\hline & $(0.08)$ & $(0.13)$ & $(0.12)$ \\
\hline \multirow[t]{2}{*}{ Father self-employed } & $1.90^{* \star}$ & $2.12^{\star \star \star}$ & 1.33 \\
\hline & $(0.56)$ & $(0.38)$ & $(0.21)$ \\
\hline \multirow[t]{2}{*}{ Household head } & $4.31^{\star \star \star}$ & 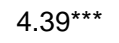 & $9.24^{\star \star \star}$ \\
\hline & $(22.24)$ & $(0.85)$ & $(1.78)$ \\
\hline \multirow[t]{2}{*}{ Children in the household } & $0.38^{\star \star *}$ & 0.85 & 0.71 \\
\hline & $(0.12)$ & $(0.16)$ & $(0.11)$ \\
\hline \multirow[t]{2}{*}{ Addis Ababa } & 0.77 & 1.05 & $0.71^{*}$ \\
\hline & $(0.23)$ & $(0.17)$ & $(0.11)$ \\
\hline \multirow[t]{2}{*}{ year95 } & 0.92 & 0.88 & 0.83 \\
\hline & $(0.19)$ & $(0.12)$ & $(0.10)$ \\
\hline \multirow{2}{*}{ year97 } & 0.74 & 0.82 & 0.83 \\
\hline & $(0.16)$ & $(0.12)$ & $(0.10)$ \\
\hline
\end{tabular}


Table 1 contd....

\begin{tabular}{lccc}
\hline year00 & $0.63^{*}$ & $0.75^{\star}$ & $0.72^{\star \star}$ \\
& $(0.16)$ & $(0.12)$ & $(0.09)$ \\
Mass point 1 $\left(\theta_{1}\right)$ & 1.7892 & 1.4499 & 2.3349 \\
Probability 1 $\left(\pi_{1}\right)$ & 0.3428 & 0.2105 & 0.1880 \\
Mass point 2 $\left(\theta_{2}\right)$ & 6.9807 & 4.5897 & 5.2136 \\
Probability 2 $\left(\pi_{2}\right)$ & 0.1872 & 0.1500 & 0.0958 \\
Mass point 3 $\left(\theta_{3}\right)$ & -8.9121 & -2.4574 & -1.7186 \\
Probability 3 $\left(\pi_{3}\right)$ & 0.3677 & 0.5862 & 0.6887 \\
& 13.264 & 8.3887 & 8.9072 \\
Mass point 4 $\left(\theta_{4}\right)$ & & & \\
Probability 4 $\left(\pi_{4}\right)$ & 0.1023 & 0.0533 & 0.0275 \\
No. of level 1 units & 5258 & 11184 & 18799 \\
No. of level 2 units & 2677 & 5320 & 8736 \\
Log-likelihood & -1285 & -1884 & -2245 \\
\hline
\end{tabular}

Note: 1. Reported results of covariate estimates are exponentiated form of coefficients

5. Figures in bracket are standard errors

6. ${ }^{* \star *}$ significant at $1 \%$; ${ }^{* *}$ significant at $5 \%$; * significant at $10 \%$

7. Columns 1, 2 and 3 represent the different reference groups used involving employees; employees and the unemployed; and employees, the unemployed and the inactive, respectively. 
Table 2: Random effects probit estimates of the determinants of self-employment (employer \& own account worker)

\begin{tabular}{|c|c|c|c|}
\hline & $\operatorname{Exp(b)}$ & $\operatorname{Exp(b)}$ & $\operatorname{Exp}(b)$ \\
\hline & 1 & 2 & 3 \\
\hline \multirow[t]{2}{*}{ Age } & $0.90 * \star \star$ & $0.87^{\star \star \star}$ & $0.88^{\star \star \star}$ \\
\hline & (0.04) & $(0.02)$ & $(0.01)$ \\
\hline \multirow[t]{2}{*}{ Agesq } & $1.002^{\star * \star}$ & $1.003^{\star \star *}$ & $1.001^{* * *}$ \\
\hline & $(0.00)$ & $(0.00)$ & $(0.00)$ \\
\hline \multirow[t]{2}{*}{ Female } & $3.37^{\star \star \star}$ & $2.33^{\star \star \star}$ & $0.72^{\star \star}$ \\
\hline & (0.92) & $(0.31)$ & (0.09) \\
\hline \multirow[t]{2}{*}{ Married } & $0.53^{\star *}$ & $1.25^{\star \star *}$ & 1.11 \\
\hline & $(0.16)$ & $(0.19)$ & (0.15) \\
\hline \multirow[t]{2}{*}{ Migrant } & $0.42^{* *}$ & $0.49 * \star \star$ & 0.75 \\
\hline & $(0.18)$ & (0.09) & (0.11) \\
\hline \multirow[t]{2}{*}{ No health problem } & 0.83 & 0.96 & 0.97 \\
\hline & $(0.16)$ & $(0.12)$ & (0.10) \\
\hline \multirow[t]{2}{*}{ TV set in the house } & $0.13^{\star \star *}$ & $0.49 * \star *$ & $0.62^{\star * *}$ \\
\hline & $(0.04)$ & (0.07) & (0.08) \\
\hline \multirow[t]{2}{*}{ Amhara } & 0.09 & $0.13^{\star \star \star}$ & $0.20^{\star * *}$ \\
\hline & $(0.04)^{\star \star \star}$ & $(0.03)$ & $(0.04)$ \\
\hline \multirow[t]{2}{*}{ Oromo } & $0.05^{\star \star \star}$ & $0.12^{\star \star \star}$ & $0.20^{\star \star \star}$ \\
\hline & $(0.04)$ & $(0.03)$ & $(0.04)$ \\
\hline \multirow[t]{2}{*}{ Tigrawi } & $0.23^{\star \star \star}$ & $0.37^{\star \star \star}$ & $0.20^{* * *}$ \\
\hline & (0.12) & $(0.10)$ & $(0.05)$ \\
\hline \multirow[t]{2}{*}{ Gurage } & 1.54 & $0.84^{*}$ & $0.70 *$ \\
\hline & (0.68) & $(0.21)$ & $(0.14)$ \\
\hline \multirow[t]{2}{*}{ Orthodox Christian } & $0.50^{*}$ & $0.13^{\star \star *}$ & $0.16^{\star \star \star}$ \\
\hline & (0.18) & $(0.03)$ & $(0.03)$ \\
\hline \multirow[t]{2}{*}{ Muslim } & $3.63^{*}$ & 0.42 & $0.37^{\star \star \star}$ \\
\hline & (2.73) & (0.11) & (0.09) \\
\hline \multirow[t]{2}{*}{ Primary level education } & 1.52 & $1.55^{\star \star \star}$ & $2.08^{\star * \star}$ \\
\hline & $(0.46)$ & $(0.25)$ & $(0.33)$ \\
\hline \multirow[t]{2}{*}{ Secondary or more } & $0.11^{\star * *}$ & $0.18^{\star \star *}$ & 0.91 \\
\hline & $(0.04)$ & (0.03) & $(0.16)$ \\
\hline \multirow[t]{2}{*}{ Has access to credit } & $0.42^{\star \star \star}$ & 0.81 & $0.53^{\star * \star}$ \\
\hline & $(0.12)$ & $(0.11)$ & $(0.07)$ \\
\hline \multirow[t]{2}{*}{ Father self employed } & $2.35^{\star \star \star}$ & $1.99 * \star \star$ & $1.59 * * \star$ \\
\hline & $(0.55)$ & $(0.27)$ & $(0.20)$ \\
\hline \multirow[t]{2}{*}{ Household head } & 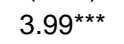 & $4.43^{\star \star \star}$ & $16.25^{\star \star \star}$ \\
\hline & $(1.89)$ & $(0.73)$ & $(2.90)$ \\
\hline \multirow[t]{2}{*}{ Children in the household } & 1.11 & $1.15^{\star \star \star}$ & 0.91 \\
\hline & $(0.26)$ & $(0.15)$ & $(0.10)$ \\
\hline \multirow[t]{2}{*}{ Addis Ababa } & 1.48 & $0.47^{\star \star \star}$ & $0.59 * \star \star$ \\
\hline & $(0.49)$ & $(0.07)$ & $(0.09)$ \\
\hline \multirow[t]{2}{*}{ year95 } & 0.87 & $0.82^{\star \star}$ & $0.87^{*}$ \\
\hline & $(0.14)$ & $(0.09)$ & $(0.08)$ \\
\hline \multirow[t]{2}{*}{ year97 } & $0.70^{\star \star}$ & $0.68^{\star \star *}$ & $0.85^{\star}$ \\
\hline & $(0.12)$ & $(0.08)$ & $(0.08)$ \\
\hline year00 & $0.64^{* *}$ & $0.66^{\star \star *}$ & $0.67^{* * *}$ \\
\hline
\end{tabular}


Table 2 contd....

\begin{tabular}{lccc}
\hline & $(0.13)$ & $(0.09)$ & $(0.07)$ \\
Mass point 1 $\left(\theta_{1}\right)$ & -1.9251 & 0.7933 & 1.9567 \\
Probability 1 $\left(\pi_{1}\right)$ & 0.1438 & 0.3068 & 0.1785 \\
Mass point 2 $\left(\theta_{2}\right)$ & 2.0397 & 4.0489 & 4.3187 \\
Probability 2 $\left(\pi_{2}\right)$ & 0.3845 & 0.1894 & 0.1273 \\
Mass point 3 $\left(\theta_{3}\right)$ & -6.928 & -3.7497 & -1.9448 \\
Probability 3 $\left(\pi_{3}\right)$ & 0.2962 & 0.4303 & 0.6455 \\
Mass point 4 $\left(\theta_{4}\right)$ & 8.8045 & 8.2074 & 7.3254 \\
Probability 4 $\left(\pi_{4}\right)$ & 0.1755 & 0.0735 & 0.0487 \\
No. of level 1 units & 6088 & 11184 & 18799 \\
No. of level 2 units & 3061 & 5320 & 8736 \\
Log-likelihood & -1835 & -2631 & -3514 \\
\hline
\end{tabular}

Note: 1. Reported results of covariate estimates are exponentiated form of coefficients

2. Figures in bracket are standard errors

3. *** significant at $1 \%$; ** significant at $5 \%$; * significant at $10 \%$.

4. Columns 1, 2 and 3 represent the different reference groups used involving employees;

employees and the unemployed; and employees, the unemployed and the inactive, respectively. 
Table 3: Descriptive statistics, dependent variable

\begin{tabular}{|c|c|c|c|}
\hline Dependent variable* & Mean & Std. dev. & No. of obs. \\
\hline & \multicolumn{3}{|c|}{ Year $=1994$} \\
\hline Employer1 & 0.020 & 0.140 & 1500 \\
\hline Employer2 & 0.011 & 0.105 & 3289 \\
\hline Employer3 & 0.007 & 0.082 & 5485 \\
\hline Employer \& own account worker1 & 0.337 & 0.473 & 1500 \\
\hline Employer \& own account worker2 & 0.189 & 0.391 & 3289 \\
\hline \multirow[t]{2}{*}{ Employer \& own account worker3 } & 0.114 & 0.317 & 5485 \\
\hline & \multicolumn{3}{|c|}{ Year $=1995$} \\
\hline Employer1 & 0.014 & 0.116 & 1370 \\
\hline Employer2 & 0.007 & 0.085 & 2865 \\
\hline Employer3 & 0.004 & 0.067 & 4716 \\
\hline Employer \& own account worker1 & 0.335 & 0.472 & 1370 \\
\hline Employer \& own account worker2 & 0.180 & 0.384 & 2865 \\
\hline \multirow[t]{2}{*}{ Employer \& own account worker3 } & 0.109 & 0.312 & 4716 \\
\hline & \multicolumn{3}{|c|}{ Year $=1997$} \\
\hline Employer1 & 0.012 & 0.110 & 1204 \\
\hline Employer2 & 0.007 & 0.081 & 2566 \\
\hline Employer3 & 0.004 & 0.064 & 4169 \\
\hline Employer \& own account worker1 & 0.329 & 0.470 & 1204 \\
\hline Employer \& own account worker2 & 0.176 & 0.381 & 2566 \\
\hline \multirow[t]{2}{*}{ Employer \& own account worker3 } & 0.109 & 0.311 & 4169 \\
\hline & \multicolumn{3}{|c|}{ Year $=\mathbf{2 0 0 0}$} \\
\hline Employer1 & 0.018 & 0.133 & 1184 \\
\hline Employer2 & 0.010 & 0.098 & 2464 \\
\hline Employer3 & 0.005 & 0.073 & 4429 \\
\hline Employer \& own account worker1 & 0.298 & 0.457 & 1184 \\
\hline Employer \& own account worker2 & 0.160 & 0.367 & 2464 \\
\hline Employer \& own account worker3 & 0.089 & 0.285 & 4429 \\
\hline
\end{tabular}

Note: The six dependent variables in each year in Table 3 represent 'employer' and 'employer and own account worker' used in the empirical analysis carried out. In each year, these variables assume same number of 'employer' and 'employer \& own account worker' but with different reference categories. Thus, the reference category in 1 is employees, in 2 employees \& the unemployed and in 3 employees, the unemployed and the inactive, all within the age range of $16-65$. 
Table 4: Descriptive statistics, covariates

\begin{tabular}{|c|c|c|c|c|c|c|c|c|}
\hline \multirow{2}{*}{$\begin{array}{c}\text { Wave } \\
\text { Variable }\end{array}$} & \multicolumn{2}{|c|}{1994} & \multicolumn{2}{|c|}{1995} & \multicolumn{2}{|c|}{1997} & \multicolumn{2}{|c|}{2000} \\
\hline & Mean & $\begin{array}{l}\text { Std. } \\
\text { Dev. }\end{array}$ & Mean & $\begin{array}{l}\text { Std. } \\
\text { Dev. }\end{array}$ & Mean & $\begin{array}{l}\text { Std. } \\
\text { Dev. }\end{array}$ & Mean & $\begin{array}{l}\text { Std. } \\
\text { Dev. }\end{array}$ \\
\hline Age & 30.868 & 13.100 & 31.126 & 12.559 & 32.605 & 12.354 & 31.890 & 13.463 \\
\hline Agesq & 1124.389 & 967.734 & 1126.531 & 929.954 & 1215.650 & 946.890 & 1198.194 & 995.194 \\
\hline Female & 0.552 & 0.497 & 0.561 & 0.496 & 0.571 & 0.495 & 0.561 & 0.496 \\
\hline Married & 0.326 & 0.469 & 0.328 & 0.470 & 0.328 & 0.469 & 0.279 & 0.449 \\
\hline Migrant & 0.167 & 0.373 & 0.161 & 0.367 & 0.150 & 0.357 & 0.082 & 0.274 \\
\hline $\begin{array}{l}\text { No health } \\
\text { problem }\end{array}$ & 0.143 & 0.350 & 0.153 & 0.360 & 0.166 & 0.372 & 0.099 & 0.299 \\
\hline $\mathrm{TV}$ in the $\mathrm{HH}$ & 0.395 & 0.489 & 0.367 & 0.482 & 0.362 & 0.480 & 0.410 & 0.492 \\
\hline Amhara & 0.520 & 0.500 & 0.522 & 0.500 & 0.524 & 0.499 & 0.507 & 0.500 \\
\hline Oromo & 0.168 & 0.374 & 0.166 & 0.372 & 0.168 & 0.374 & 0.192 & 0.394 \\
\hline Tigrawi & 0.099 & 0.298 & 0.093 & 0.291 & 0.094 & 0.292 & 0.092 & 0.289 \\
\hline Gurage & 0.128 & 0.334 & 0.131 & 0.337 & 0.130 & 0.337 & 0.133 & 0.339 \\
\hline $\begin{array}{l}\text { Orthodox } \\
\text { Christian }\end{array}$ & 0.808 & 0.394 & 0.811 & 0.391 & 0.812 & 0.391 & 0.794 & 0.404 \\
\hline Muslim & 0.128 & 0.334 & 0.125 & 0.330 & 0.124 & 0.329 & 0.130 & 0.336 \\
\hline $\begin{array}{l}\text { Primary } \\
\text { education }\end{array}$ & 0.400 & 0.490 & 0.405 & 0.491 & 0.407 & 0.491 & 0.352 & 0.478 \\
\hline $\begin{array}{l}\text { Secondary or } \\
\text { more }\end{array}$ & 0.302 & 0.459 & 0.292 & 0.455 & 0.286 & 0.452 & 0.289 & 0.453 \\
\hline $\begin{array}{l}\text { Has access to } \\
\text { credit }\end{array}$ & 0.755 & 0.430 & 0.742 & 0.438 & 0.741 & 0.438 & 0.630 & 0.483 \\
\hline $\begin{array}{l}\text { Father self- } \\
\text { employed }\end{array}$ & 0.585 & 0.493 & 0.576 & 0.494 & 0.572 & 0.495 & 0.453 & 0.498 \\
\hline $\mathrm{HH}$ head & 0.239 & 0.426 & 0.222 & 0.416 & 0.211 & 0.408 & 0.197 & 0.398 \\
\hline $\begin{array}{l}\text { Children in the } \\
\mathrm{HH}\end{array}$ & 0.279 & 0.449 & 0.281 & 0.449 & 0.281 & 0.449 & 0.229 & 0.420 \\
\hline Addis Ababa & 0.657 & 0.475 & 0.658 & 0.474 & 0.669 & 0.471 & 0.655 & 0.475 \\
\hline $\begin{array}{l}\text { No of } \\
\text { observations }\end{array}$ & \multicolumn{2}{|c|}{5500} & \multicolumn{2}{|c|}{4708} & \multicolumn{2}{|c|}{4152} & \multicolumn{2}{|c|}{4439} \\
\hline
\end{tabular}

